\title{
Does the Sustainability of the Anthropocene Technosphere Imply an Existential Risk for Our Species? Thinking with Peter Haff
}

\author{
João Ribeiro Mendes ${ }^{1,2}$ (D)

Citation: Mendes, João Ribeiro. 2021. Does the Sustainability of the Anthropocene Technosphere Imply an Existential Risk for Our Species? Thinking with Peter Haff. Social Sciences 10: 314. https://doi.org/ 10.3390/socsci10080314

Academic Editors:

Manuel Arias-Maldonado and Nigel Parton

Received: 28 June 2021

Accepted: 16 August 2021

Published: 19 August 2021

Publisher's Note: MDPI stays neutral with regard to jurisdictional claims in published maps and institutional affiliations.

\begin{abstract}
Throughout the 20th century, several thinkers noticed that Technology was becoming a global phenomenon. More recently, US geologist Peter Haff claimed that a Technosphere is now in place and can be conceived as a new Earth geological system. This unprecedented situation is creating enormous challenges not only for our species, since more and more of its members are now dependent on the subsistence of this man-made sphere, but also for other species and natural ecosystems that have become increasingly dependent on it. Perhaps the most crucial of these challenges is the sustainability of the Technosphere itself. In the first part of the article, I attempted a critical reconstruction of Haff's Technosphere concept. The second part is dedicated to analyzing how the unsustainability of the Technosphere represents a global catastrophic risk and ultimately an existential risk.
\end{abstract}

Keywords: technosphere; anthropocene; Peter Haff; sustainability; existential risk

\section{Introduction}

At the beginning of The Decay of Lying, in a scene set in the library of a country house in Nottinghamshire, Cyril — the pro-naturalist—says to Vivian — the anti-naturalist:

If Nature had been comfortable, mankind would never have invented architecture, and I prefer houses to the open air. In a house, we all feel of the proper proportions. Everything is subordinated to us, fashioned for our use and our pleasure. (Wilde [1889] 1905, p. 4).

In this well-known essay on the relationship between Art and Nature, the Irish writer Oscar Wilde proclaims the anti-Aristotelian thesis that it is Nature which should imitate Art, not the reverse as the Stagirite claimed, because Nature remains always unfinished and imperfect. This means, in other terms, that we have a duty - in the moral sense-to impose Art on Nature.

Mutatis mutandis, identical duty can be affirmed in relation to Technology. We too must impose it on Nature. In fact, both concepts of Art and Technology have the same root-Technê-as they represent poietic activities that seem to differ only in their purpose, disinterested in the first and pragmatic in the second. In the evolutionary process of our species, we have never ceased to create technologies to repair or compensate for the imperfections of Nature and yet make our existence more adapted to circumstances and more comfortable (Technology as Anthropologically Constitutive/Constituent thesis of the School of Compiègne; Steiner 2010). In addition, we have also continually linked these technologies, the degree of complexity of which has increased to the point that more recently they have given rise to a Technosphere, a mesh of interconnected technical artifacts that covers our planet and which increasingly seems to have a life of its own or independent of its creators. 
Taking inspiration from Jean Baudrillard, we can say that this Technosphere seems to be a hypertelic effect resulting from a fatal strategy, one that has been successful until a certain moment and point, but which later generated an unplanned and unforeseen excess.

The French sociologist introduced a distinction between "banal strategies", those in which the subject believes to be more masterful and sovereign than the object it has created or have to deal with, and "fatal strategies", those in which the subject recognizes the supremacy of the object and surrenders to its rules (Baudrillard 1983, p. 260). One of those fatal strategies he explored was that of Hipertely.

Hipertely is not an accident that occurs in the evolution of a system (natural or artificial), but rather a response to its increasing complexity and indeterminacy, in the form of effects that surpass its end and threaten it in its entirety (p. 12). An example given by Baudrillard is that of obesity, in which the fat cells, programmed to defend the body, grow to such an extent that they become dysregulated and immobilize and slowly kill it (p. 29).

The evolution of the Technosphere can be conceived in a similar way. Originally designed to correct and perfect Nature, it seems increasingly oriented towards self-correction and self-melioration, but mobilizing and using resources taken from Nature itself, which make it increasingly unsustainable and puts its balance at risk. So, we may have gone too far in using technology to the point that it has become hypertelic.

This, then, is the hypothesis we want to examine here: we will have built a Technosphere so extensive and intensely predatory of the natural resources necessary for its maintenance and evolution, to the point of having generated the moral consequence of which we only belatedly became aware, but which threatens decisively the continuity of our species, in its entirety or in large part, on the planet. There were two main research goals. One was to clarify the concept of the "Technosphere". It is justified because, although this concept can be conceived as having a genealogy that goes back about a century, ${ }^{1}$ it has only been semantically shaped recently by U.S. Professor of Geology Peter Haff. The first part of this article, therefore, is dedicated to the characterization of the concept of Tecnosphere, based on the work of this author. The other tries to answer the enunciated hypothesis, that is, to build an argument of a transcendental or quasi-transcendental kindthe Technosphere is a condition of material possibility for our continuity on this planet, to function as a premise for another argument of a type (more) Moral: the increase in the risk of our existence on Earth varies with the increase in the emerging risk of an unsustainable development of the Technosphere. The second part will be dedicated to this task.

There is a vast amount of literature on the extraction, transformation, and excessive consumption of energy resources and raw materials by our species, which has intensified since the beginning of modernity in the 17th century and accelerated after World War II in the mid-20th century. This literature has revealed how such depletion activities can threaten the sustainable development of small to large terrestrial socio-ecological systems (e.g., Arias-Maldonado 2015; Fremaux 2019, esp. chp. 4) and even of the Earth System as a whole, mainly by the transgression of the so-called "planetary boundaries" (e.g., Rockström et al. 2009; Steffen et al. 2015; Meyer and Newman 2020).

There is also extensive literature on discard practices, poor recycling, etc. To get a sense of this, one need only consult the list of bibliographic references collected on the "Discard Studies" website: https:/ / discardstudies.com/resources/journal-articles (Accessed on: 1 June 2021).

Of course, a vast amount of literature on global catastrophic risks is also available. See, for instance, the document with almost one hundred and a half fundamental bibliographic references on the subject compiled by the Future of Humanity Institute (http:/ / www. global-catastrophic-risks.com/docs/references-gcr.pdf-gcr.pdf; accessed on: 1 June 2021).

Finally, a significant number of studies have been published on fundamental parts of the Technosphere, namely on its material component (physical infrastructure) (e.g., Allenby 2005), on its informational component (energy flow, resource mobilization, and communication systems) (e.g., Hartley et al. 2020), and on its cultural component (institutions) (e.g., Dalby 2020). 
However, there is a gap in the available literature on the issue of the sustainability of the Technosphere and of the possibility that this is one of the greatest existential risks we face today. This does not mean that there are no studies on sustainable technologies or on the sustainability of particular technologies. A significant amount of research has been done about environmentally friendly technologies, technologies that incorporate circular economy processes, Geoengineering, Smart Earth technologies (e.g., Bakker and Ritts 2018), Earth System interventions (e.g., Reynolds 2021), the ambitious Sustainability Geoscope project (Lucht and Jaeger 2001) that never saw the light, etc. What was not investigated, at least sufficiently, I believe, was the question of the sustainability of the Technosphere itself, or in itself, that is, as an entity that behaves in a way that does not constitute a mere aggregation of the behavior of its parts, particular technologies. This question implies (re)thinking the design, architecture, and engineering of the Technosphere as a whole, but also ways to manage and govern it that go beyond the paradigm of international relations based on the nation-state, and examining in depth the unprecedented philosophical, particularly ethical-political, challenges that arise from it.

In a sense, it was only in the second decade of this century, when Peter Haff started to think of the Technosphere-literally, an artificial sphere in which the Earth is involved-in an external (or extraterrestrial) way, that is, in a global and integrated perspective, to better understand what goes on inside it, especially how it relates to the planet's natural spheres, that this issue began to be effectively addressed.

\section{The Technosphere}

\subsection{Definition}

The concept of "Technosphere" was introduced by Peter Haff in his paper "Technology and human purpose: The problem of solids transport on the Earth's surface" ${ }^{2}$ He defined it as "(...) widely distributed and interconnected technological systems on whose function modern civilization and society are based" (Haff 2012, p. 149).

In the article "Technology as a geological phenomenon: Implications for human wellbeing", published the following year, Haff reiterated this definition by stating that the Technosphere is:

“( $\ldots$ ) the set of large-scale networked technologies that underlie and make possible (... ) "artificial" or "non-natural" processes [extraction and processing of raw materials; energy production; electronic communications; transport of goods and merchandise; food industry; political and economic bureaucracies; etc.] without which modern civilization and its present $7 \times 10^{9}$ human constituents could not exist". (Haff 2013, pp. 301-2).

The Technosphere, therefore, corresponds to the domain of Technology. Its representation as a sphere serves to suggest imagetically that it has acquired a form that accompanies and involves that of the Earth itself. It seems like a set of interconnected technologies weaving a reticular mesh that covers the planet, composing a total system in appearance. Beyond this form and this aspect, each technology that makes up the network serves a specific purpose and, at the same time, contributes to the greater purpose of ensuring the subsistence and functioning of contemporary human civilization. ${ }^{3}$

Haff seems to understand that the emergence of the Technosphere is the result of a process that took place in the last two centuries of progressive dissemination and interconnection of a multitude of technologies to the point of forming a kind of planetary network.

He also seems to conceive, at least implicitly, that although the Technosphere is a heterogeneous set of interconnected technologies, it constitutes a relatively homogeneous entity.

The preference for the name "Technosphere" rather than "Anthroposphere", Haff explained, was because although almost synonymous, the former seems more semantically neutral than the latter and more appropriate for a more objective analysis of the phenomenon (Haff 2013, p. 302). 
A fourth noteworthy aspect is the analogy he established between the so-called classical geological paradigms and this emerging one (Haff 2013, p. 302). As is well known, Eduard Suess introduced in Die Entstehung der Alpen (The Emergence of the Alps) the geological image that planet Earth can be described as a set of spheres (Suess 1875). In that same book, the Austrian geologist also made use, for the first time, of the concept of "Biosphere", defined as a thin layer at the intersection of the Lithosphere, Hydrosphere, and Atmosphere (this last was already in circulation since the 1700s, the others were coined by Suess). Given Haff's background in Geology, it is not surprising that he wanted to connect with this conceptual tradition inaugurated by Suess.

Finally, according to him, the Technosphere was created by the human species with the main objective of establishing the conditions for modern civilizational life.

\subsection{Properties}

Haff (2013) claimed that all four natural geological spheres possess five fundamental properties-they have a global extension, they take over pre-existing structural and metabolic resources, they preserve the structure and functionality of pre-existing spheres, they recycle their resources, they have autonomy-and that the Technosphere has all of them, at least to some degree.

The first seems rather obvious, because " (. . ) technology penetrates to nearly every part of the globe through a web of communication and transportation networks" (Haff 2013, p. 302) and " (. . ) is in any practical sense a global phenomenon, spanning the planet and absorbing into itself almost all of the world's human population" (Haff 2013, p. 303). ${ }^{4}$ Indeed, we might say that a Technosphere emerged from a process that began with the 1st Industrial Revolution at the end of the 18th century, accelerated and intensified after World War II, and became a reality at the turn of the 21st century.

If we think of the modern State as a technology of political organization-one of the largest and most cohesive components of the Technosphere-we realize that it has spread throughout the entire planet and that it is now practically impossible for any human individual to remain outside of it. This is the example given by Haff of the global extent of the Technosphere.

The Technosphere, therefore, seems to have been built in an unplanned way, but from the moment it became a reality, it brought deep changes to the Human-Technology-Nature relationship.

The second property is also explicit. The physical components of a geological paradigm", says Haff, "are constructed from parts cadged from the Earth's supply of resources, including from resources used by older paradigms" (Haff 2013, p. 303). If so, it is quite clear that the Technosphere extracts and appropriates matter (water, organic material, oxygen, etc.), energy, and information (DNA) from the main natural spheres.

Domestic animals, like most of the physical organisms, and even more and more human beings were born directly into the Technosphere and " . . ) can be viewed as newly constructed technological parts based on old design information (DNA) captured from the biosphere" (Haff 2013, p. 303). Many of them seem to owe their existence to the technological processes that support them and, at the same time, to be indispensable to support them.

The Technosphere also shows to have the third referred property: it preserves the structure and functionality of pre-existing geological paradigms, i.e., it appropriates " (... ) large quantities of "natural resources" from the biosphere, hydrosphere and lithosphere, but, at least for the time being, the ancient paradigms continue as globally organized systems" (Haff 2013, p. 304).

Indeed, the so-called "natural capital"—_" . . . ) the Earth's thick, fertile soils, mineral resources, bacterial and chemical populations that breakdown or recycle wastes, sources of fresh water, soil mechanisms that filter or detoxify contaminants, a reasonably stable and equable climate, and biological diversity, among many other examples" (Haff 2013, p. 304)_- 
is determinant of the subsistence and functioning of the Technosphere and ultimately of human well-being.

This means that the Technosphere faces the permanent challenge of maintaining a harmonious and balanced relationship with the other natural geological spheres, at the risk of endangering its subsistence and that of its components, namely human beings. Unlike other natural spheres, the sphere of Technology has the distinctive property, through its human components, of becoming aware of its own functioning and thus having the power to direct and change it. However, that conservative process is being abandoned, and its sustainability, if not its existence, is increasingly at risk.

In close relationship with the latter, the fourth property is also present in the Technosphere: the recycling of resources. Each geological paradigm needs to do so, not only to avoid the depletion of such resources but also to prevent the limitation of its own activity. Furthermore, as Haff also points out, since the Earth is a closed metabolizing system (essentially with no mass input or output), it must recycle its own waste, otherwise too much accumulated polluting material will render the system unable to function.

Today, the Technosphere reveals poor recycling capacity for many of the critical resources it uses. If this continues, in the not too distant future, it could lead to a catastrophic reorganization of the Earth and more dramatically to the eventual extinction of our species.

Finally, the Technosphere also has the property of autonomy. Martina Heßler (2019) pointed out that the problem of technological autonomy is essentially about the position of human beings in relation to the Technology created by themselves. According to her, this problem has a complex cultural history that goes back to ancient Greece, but in the past two centuries, it has remained centered on the anthropological, social, political, and economic consequences of the creation of machines programmed to work without human intervention.

In the same vein, Haff stated that, although different from the four natural spheres, which seem to dispense with deliberation and human control to function, we tend to see Technology as "(...) not autonomous, but critically dependent on human beings and human actions" (Haff 2013, p. 306). The fact is that the Technosphere, created by human beings, at a certain moment will have acquired a high degree of autonomy, to the point of raising the question about whether and to what extent the Technosphere still needs its creators to survive.

The gain of autonomy, at the level of the Technosphere as a whole and not at the level of its parts, occurred after the acquisition of a global extension. Haff implies that Technosphere's autonomy was not planned, but resulted from a type of hypertelic process. It was designed and built by human beings to serve their interests and expand the limits of their freedom, but it ended up transcending that purpose and reversing the relationship of dependency, that is, becoming a condition of subsistence and survival for its creators, transforming them into its components.

In sum (see Table 1), says Haff, the Technosphere "( ... ) exhibits a number of properties of earlier geological paradigms. It is autonomous. It is a global phenomenon. It appropriates Earth resources, including energy, mass and information, for its own uses on a large scale" (Haff 2013, p. 307), but “( . . ) unlike earlier Earth paradigms, which recycle most of their waste products, the technosphere does little recycling" (Haff 2013, p. 307).

Table 1. Summary of the properties of the geological spheres.

\begin{tabular}{ccc}
\hline Geological Domain Properties & $\begin{array}{c}\text { Natural } \\
\text { Spheres }\end{array}$ & Technosphere \\
\hline global extent & yes & yes \\
\hline $\begin{array}{c}\text { appropriation of resources from } \\
\text { pre-existing spheres }\end{array}$ & yes & yes and increasing in quantity and speed \\
\hline $\begin{array}{c}\text { preservation of structure and } \\
\text { functionality of pre-existing spheres }\end{array}$ & yes & yes, but with a tendency to change \\
\hline recycling of resources & yes & yes, but still very poor \\
\hline autonomy & yes & yes, but still in its infancy \\
\hline
\end{tabular}


There is an increasing autonomy of the Technosphere and, at the same time, a decrease in the control of it by human beings; but, on the other hand, only humans will be able to prevent the appropriation and depletion of resources, metabolic excess, and little recycling. This means that the problem of the sustainability of the Technosphere was created by human beings and can only be solved by them.

\subsection{Dynamics}

Haff (2014), in the article "Humans and technology in the Anthropocene Six rules", takes up the concept of Technosphere discussed in Haff $(2012,2013)$, but this time, describes it as a complex system with a planetary dimension.

In this text, he reaffirms the thesis that the Technosphere results from a human creation that gained relative independence from its creators. However, the degree of autonomy achieved by the Technosphere is still not sufficient to dispense with human labor in its subsistence. On the other hand, human beings cannot do without the Technosphere either, because to dismantle it in part or in total would have an unbearable existential and moral cost. $^{5}$ In a sense, the Technosphere and its human components remain co-dependent and with an apparently inseparable destiny. This means that the dynamics of the global technospheric system depend and will depend, in large part, on its relationship with its special component, which are the human agents.

Haff identifies six rules that determine the evolution of the Technosphere as a complex system of planetary dimension and, eo ipso, co-adaption with its human components. These are rules to which most people are subject and cannot escape, a new state of human affairs, "( ... ) not meant as a metaphor or analogy, but as a physical necessity, a reality" (Haff 2014, p. 129). They are rules that determine the sustainability of the Technosphere and the survival of its human (and non-human) inhabitants.

The first is the rule of inaccessibility. It states that we cannot interact directly with most of the large components of the Technosphere or, in other words, that those large components cannot directly influence the behavior of their human parts (Haff 2014, p. 130).

The relevance of this rule is, on the one hand, to make us (more) aware that we are most of the time too much focused on what is closer and familiar to us, that is on local causes and effects-Heidegger would probably say, on what is at hand. However, on the other hand, is also reminds us of the fact that we are also components of a larger system not created by any individual human being, and whose functioning we do not fully understand or control, and from which we cannot escape.

The second is the rule of impotence: most human beings cannot significantly influence the behavior of large technological systems. For example, governments do not easily change policies because of complaints from individuals, groups, or movements. There are, of course, exceptions to the rule. For instance, individuals or groups may sabotage parts of a country's power grid and cause a blackout affecting many services. This rule shows how large technological systems tend to resist not only human interference with their function, but also their modification.

The third is the rule of control. We can formulate it this way: when a technological system performs a greater range of behaviors - it is more complex - than any human being, the latter has no control over it. This does not prevent the possibility that some persons may influence their evolution. However, as Haff points out: "The technosphere is not a giant version of a navy ship" (Haff 2014, p. 132). A complex system to be controllable has to be designed so that the processes for its operability are in line with the capabilities of its handlers. The problem is that the Technosphere is not a system that has been projected and, therefore, cannot be effectively controlled by us.

In fourth comes the rule of reciprocity that enounces that an individual human being can interact directly only with systems at his own scale, for instance with a mobile phone or an automobile, but not with a microchip or the (whole) Technosphere. Ignoring this rule, according to Haff, " ( . . ) encourage[s] the anthropocentric misconception that we created and control large-scale technology" (Haff 2014, p. 133). 
A fifth one is the rule of performance: “( .. ) at least some of the actions of most system parts must support the function of the system to which they belong" (Haff 2014, p. 133). In other words, the rule states that most human beings must perform some tasks in favor of the functioning of the Technosphere.

This rule reveals that human beings are not mere users of the Technosphere, of the goods and services that are produced in it, but rather fundamental components of it. On the other hand, the Technosphere, as a technological infrastructure on a planetary scale, can no longer be seen as an instrument at the service of the human beings who created it and has become a condition for the possibility of their own existence and coexistence. As Haff crudely states:

A few individuals may occasionally withdraw from the technosphere voluntarily to become hermits, or fail to work in its support because of mental or physical incapacity, e.g., the sick and the homeless. From the point of view of the technosphere the latter are broken parts, and are in effect discarded from the system unless they can be repaired, i.e., made serviceable again. (Haff 2014, p. 133)

The last of the rules is the rule of provision: "It is necessary that the parts of a system experience an environment that makes it possible for them to perform their support function" (Haff 2014, p. 134). It implies that the Technosphere is a "host system" that contributes to maintaining a "suitable environment" for its components, or that the Technosphere must provide an environment for the survival and functioning of the human beings.

The rules of performance and provision, in particular, create conditions for positive feedback on human components, providing " (... ) gadgets, services and systems that people want ( ... )" (Haff 2014, p. 134) and stimulate expansion of the Technosphere. However, they are the ones who, in the long run, can destabilize it. This will happen, according to Haff, if the technological systems that integrate it remain or become highmetabolic and, at the same time, remain insufficiently capable of recycling the waste they produce that the natural systems of not recycle. In other words, that means that if the environmental degradation, the global warming, and the world population continues to rise, the Technosphere may fail to support the civilization that created it.

\section{The Continuity of the Technosphere as an Existential Imperative}

The problem of the sustainability of the Technosphere involves at least three challenges: how it can exist in a thermodynamic universe; how it can coexist harmoniously with existing natural spheres; and how it can maintain its essential purpose of investing the human species with power of global agency.

I will leave aside the first, which can be considered essentially a technoscientific and systems engineering challenge, and I will focus on the remaining two, which are more and more interconnected: the increasing impact of the Technosphere on our planet and the way it threatens its own subsistence and the survival of our species.

\subsection{The Technosphere as Technocene and Technotope}

In her essay The Human Condition, Hannah Arendt wrote more than six decades ago:

The most radical change in the human condition we can imagine would be an emigration of men from the earth to some other planet. Such an event, no longer totally impossible, would imply that man would have to live under man-made conditions, radically different from those the earth offers him. (Arendt [1958] 1998, p. 10)

Apparently, the German philosopher envisioned the possibility of Terraformingshaping Earth's environmental conditions on another planet to make it habitable by humans-but not of building an artificial layer surrounding our entire planet, a manmade Technosphere.

Yet, since the middle of the 18th century, several generations have built this vast technological (infra)structure which reached its planetary scale around the last quarter of 
the 20th century. That is why it can be claimed, as Peter Haff does, that the Anthropocene and the Technosphere are coeval.

Crutzen and Stoermer (2000) introduced the neologism "Anthropocene" to refer to the new geological era that we are supposed to have entered, in which the state of the Earth System, predominant in the previous 11,700 years of the Holocene-the last chapter of the official history of Earth-of relative amenity and climatic stability, would have changed and become hostile and unstable, mainly because of human action. However, this unprecedented power acquired by our species to intervene and cause changes in the Earth System or in the major Earth subsystems can only be exercised in an effective and efficient way through the Technosphere. Yuk Hui, one of the most influential philosophers of technology today, even speaks of "(...) a gigantic cybernetic system in the process of realization" (Hui 2017, p. 2) as a determinant of this new geocivilizational era.

As a result, some authors_-e.g., Hornborg (2015); Cera (2017)—argued that it would be preferable to call this new era, in a less narcissistic way, Technocene instead of Anthropocene. According to them, more than in an era dominated by humans, we live in an era in which Technology is dominant and subjugating. The temporal suffix "-kainos"particularly used in scientific geochronology—combined with "techno-" denotes this new age in which we live.

However, the Technosphere is not just a Technocene. It is also a Technotope, as for instance, Erlach (2000) and Kockelkoren (2007) argue. The Tecnosphere is, therefore, a place, a "topos". Erlach (2007) expressed it very clearly in the following terms:

The Technosphere is-like the Biosphere-the aggregate of technical artefacts, resources and, finally yet importantly, waste. The socio-technologically designed place of life of man, set up with the aggregate of technical artefacts that are generated, used and consumed under social conditions on the one hand, and on the other hand bring about, shape and change these social conditions through their production, installation and application, can be analogous to describe a Biotope as a Technotope. Accordingly, the Technotope is the human-inhabited, technomorphically shaped region, its sociotechnical world (p. 138). ${ }^{6}$

Jacques Ellul called it " ( . . ) the new and specific milieu in which man is required to exist, one which has supplanted the old milieu, viz., that of nature" (Ellul 1963, p. 10). Jan Van Boeckel (2015), in a comment to his work, added that "( . . ) technology has become an environment: the technological milieu-our technotope-is not only the place where we live, but it also makes living possible and forces change; it obliges us to transform who we are because of the problems arising from the milieu itself"' (p. 215). (see Table 2)

Table 2. Technosphere, Technocene, and Technotope.

\begin{tabular}{|c|c|}
\hline \multicolumn{2}{|c|}{$\begin{array}{l}\text { Technosphere } \\
\text { the set of large-scale networked technologies that underlie and make possible modern civilization } \\
\text { and the existence of the present } 7 \times 10^{9} \text { human beings (Haff) } \\
\text { a gigantic cybernetic system in the process of realization (Yuk Hui) }\end{array}$} \\
\hline as Technocene & as Technotope \\
\hline $\begin{array}{l}\text { a new era in which Technology is dominant } \\
\text { and subjugating (Hornborg; Cera) }\end{array}$ & $\begin{array}{c}\text { a new and specific milieu in which man is } \\
\text { required to exist (Ellul) } \\
\text { an (artificial) environment (van Boeckel) } \\
\text { the human-inhabited, technomorphically } \\
\text { shaped region, or sociotechnical world (Erlach; } \\
\text { Kockelkoren) }\end{array}$ \\
\hline
\end{tabular}

Those seem to be the unavoidable new temporal-spatial coordinates for our global coexistence. Haff (2013) even asserted that we " (. . ) have become entrained within the matrix of technology and are now borne along by a supervening dynamics from which they cannot simultaneously escape and survive" and "[i]n this sense one might say that technology is the next biology" (p. 302). 


\subsection{The Unbearable Burden of the Technosphere}

There are perhaps too many definitions for the concept of "sustainability"—or "sustainable development", since they can be taken as practically synonymous. Johnston et al. (2007) found in the academic literature more than three hundred definitions, and Pearce and Walrath (2008) collected eighty-three.

More recently, Döbel (2014) outlined a history of the notion, confirming this semantic profusion, but pointing out two things. First, that the term became known worldwide through its definition in the 1987 Brundtland Commission report Our Common Future (Brundtland 1987). Here is the canonical passage: "Sustainable development is development that meets the needs of the present without compromising the ability of future generations to meet their own needs" ( 27 ). Second, that the systemic approach become somewhat prevalent in sustainability studies. For example, Ben-Eli, a recognized expert in this field and the founder of the Sustainability Laboratory, described "sustainability" as:

A dynamic equilibrium in the process of interaction between a population and the carrying capacity of its environment such that the population develops to express its full potential without producing irreversible, adverse effects on the carrying capacity of the environment upon which it depends. (Ben-Eli 2012, p. 297).

In this respect, Döbel also emphasized that all definitions of sustainability share the idea that future human beings should enjoy their lives as fully, at least, as those of current generations, and, therefore, that human beings in the present must be careful not to destroy the preconditions for the good-life of future humans (Döbel 2014, p. 36).

Thus, the question of the sustainability of the Technosphere means that it must be able to persist indefinitely and means too that it must coexist in homeostasis with the main natural ecosystems on Earth. If it fails to do so, not only the basic needs and aspirations of future generations will not reasonably ensured, but, more crucially, the Earth System, its biodiversity, and our global civilization will be threatened in their survival.

However, the current impact exerted by the Technosphere on other Earth's spheres motivates serious concern. Gupta and Hecht (2017), e.g., concluded that “( . . ) there's now enough concrete on the planet to produce a $2 \mathrm{~mm}$ thick, full-scale replica of Earth, and enough plastic to completely wrap that replica in cling film". The growth of the so-called megacities is another more compelling example. Indeed, if we look at Technosphere's infrastructure - that should not be confused with the informational structure and cultural systems that are also part of it-these urban agglomerations with 10 or more million inhabitants stand out. They are attractors and polarizers of gigantic population aggregates. They may give us some clues about the difficulties that the above-referred second challenge faces, namely in terms of waste production and management, and the current poverty of recycling processes.

UCLA Geography Professor Laurence Smith, in the second chapter of his 2011 widely read The New North: Our World in 2050 predicts that in 2025 there will be around thirty megacities in the world, almost fifteen times more than in 1950 (Smith 2011). However, if we consider urban construction on a planetary scale it is estimated at about 11 trillion metric tons, with the cities making up 36.9\% of the Technosphere (Zalasiewicz et al. 2017; Soppelsa 2017).

The development of the Technosphere is deeply connected with the process of urbanization. In a sense, this process is an effective way of amplifying human individual agency through collective action. However, it also seems to be producing huge unmanageable negative externalities, mainly domestic-generated unusable waste.

The so-called "waste layer" created by the Technosphere (also within the Technosphere itself), and the endogenous current incapacity it has to metabolize most of its components, especially the dangerous ones (e.g., toxic chemicals), is not only a threat to the regular functioning of the natural spheres, as it is also a growing risk for the normal operation of the Technosphere.

For instance, a top megacity, such as New York, has been producing an average of 20 million tons of waste per year in the current decade. If we project this number to the 
foreseeable thirty megacities in less than five years, it is conceivable that they alone will generate the staggering volume of more than 1 trillion tons of waste per year from the middle of the decade onwards.

Haff (2013) argued that:

Policies that are based only on a consideration of future human wellbeing and do not take into account the needs of technology, especially the need to continue metabolizing at a high rate-which is the source of the constraints and incentives that channel human behavior towards technology-friendly activities and is thus the sine qua non of technologyare likely to fail or be slow to implement because they consider the implicit two-way compact between system and parts only from the viewpoint of the parts (p. 307).

And shortly after that we can try to solve recycling problems using "renewable technologies", but since these renewable technologies are technologies, that has the paradoxical consequence of further expanding the Technosphere and depleting more natural resources.

However, Donges et al. (2017) pointed out that “Haff's perspective appears incompatible with a humanistic view that underlies the sustainability discourse at large and, more specifically, current frameworks such as UN sustainable development goals and the safe and just operating space for humanity" (p. 23). Furthermore, we can say that although the Technosphere seems to acquire more and more autonomy in its operation, and humans are increasingly relegated to operate in its backstage, it cannot be ignored that only humans will be able to reduce appropriation and avoid depletion of resources, to prevent metabolic excesses, and to improve recycling. In short, the sustainability problem of the Technosphere was created by humans and can only be solved by them.

\subsection{Humankind Risks Extinction?}

Why is the question of the sustainability of the Technosphere so anthropologically dramatic? Because, as it was argued above, the Technosphere constitutes a Technocene and a Technotope. It is no longer just a technological infrastructure in which we live our lives, but an artificial habitat, from which we cannot escape, to which we have to adapt, which determines our life modes and styles, the condition of the possibility of the continuity of our species, and our civilization. In other words, the question of the sustainability of the Technosphere seems more and more a global catastrophe risk and an existential risk.

Nick Bostrom and Milan Ćirković, in the book they published as editors, Global Catastrophic Risks, define "global catastrophic risk" as one attributable to some event " (... ) that might have the potential to inflict serious damage to human well-being on a global scale" (Bostrom and Ćirković 2008, p. 1). According to them, a catastrophe that causes 10,000 fatalities or 10 billion euros of economic damage (e.g., a major earthquake) is not a global catastrophic risk, but a catastrophe that causes 10 million fatalities or 10 trillion euros of economic losses (e.g., a pandemic) constitutes a global catastrophic risk, even if some region of the world escapes unscathed.

Following Bostrom and Ćirković, we can characterize approximately the severity of a risk by three variables: (a) its scope, that is, how many people and other morally relevant beings would be affected-they can be personal (affecting only one person), local, global (affecting large part of the human population), and transgenerational (affecting not only the current population, but all generations that may exist in the future); (b) their intensity, that is, how severely these would be affected - they can be imperceptible (hardly noticed), endurable (causing significant damage, but not completely destroying quality of life), and terminal (causing death or permanently and drastically reducing quality of life); and (c) its probability (what is the likelihood of the disaster occurring, according to our best assessment, given the evidence currently available.

Consequently, an event with global catastrophic risk is, at the risk of redundancy, global or transgenerational in scope and endurable or terminal in intensity. A subset of these is that of existential risks. Bostrom and Ćirković (2008) define an event with "existential risk" as " $(\ldots)$ ) one that threatens to cause the extinction of Earth-originating intelligent life or to reduce its quality of life (compared to what would otherwise have 
been possible) permanently and drastically" (p. 4). A fundamental characteristic of this class of risky events is that they are irreversible, that is, we cannot recover from them. Therefore, we cannot allow an existential disaster to happen, because we would not have the opportunity to learn from such an experience.

This is one of the biggest challenges of our time: finding effective and efficient ways to prevent the unsustainability of the Technosphere we inhabit from becoming an existential risk.

Thomas (2020) argued that the complexity involved in this challenge cannot be addressed with an interdisciplinary approach that seeks to integrate different types of knowledge to produce a single, coherent synthesis, or, as she prefers, a "single story". According to her, the Anthropocene Technosphere is too complex an entity for such an approach, as it is multifaceted and multiscalae, and therefore requires new forms of knowledge production. She warns that there is no single solution to this problem within reach and that social scientists and humanists in particular must beware of their tendency to oversimplify the task.

Karlsson (2021, p. 1), in turn, regarding this same challenge, recently cautioned that two factors, still insufficiently considered, seem to be contributing significantly to increasing the degree of this risk. On the one hand, the procrastination of measures in favor of a long-term sustainable global trajectory is causing us to fall into the potentially dangerous trap of requiring "ever greater measures of proactionary risk-taking". On the other hand, false perceptions-or "optical illusions" as the author calls them- that were generated from an alleged planetary regeneration resulting from temporary reductions in emissions due to the COVID-19 epidemic tend to "to obscure worsening global trends" and reinforce the political disinterest in developing the Technosphere to be "more compatible with universal human development and worldwide ecological restoration".

\section{Conclusions}

We are today, and from now on, condemned to inhabit and live our lives, as individuals and as a species, in a planetary Technosphere.

It has its ultimate root in our species' evolutionary adaptation schemes, but it ended up transcending them.

This autonomization of the Technosphere in relation to its human creators, only made unequivocal in the contemporary era-more clearly in the last 25 years or so-means that it has developed according to an internal and proper logic not necessarily compatible with human interests and purposes.

This growing mismatch between the Technosphere and Humanity can be interpreted both as a result of the growing "obesity" of both, who grow immeasurably alongside each other and demanding of each other. However, it can also be interpreted as a sustainability problem in the sense of controlling existential risks that already seem unavoidable.

In any case, the biggest challenge that currently coexisting generations today and the closest future generations both face is to seriously and thoroughly rethink our/their planetary technological condition or, in other words, the fate of Humanity as inextricably linked to that of the Technosphere.

I believe that the critical examination carried out in this article is a contribution to initiate a broader and deeper reflection on the moral implications of the eventual unsustainability of the Technosphere. In fact, it converges with the effort initiated by Carsten Herrmann-Pillath (2017) to establish a "Science of the Technosphere". This project of a new independent scientific discipline aims, but not only, to elaborate an ethical theory to meet the enormous geocivilizational challenge we are currently facing and allow us to have (some) power to control the unlimited and unrestrained growth of human desires that are undermining the sustainability of the Earth System and the biosphere.

In a certain sense, it might be preferable to speak of the urgent need for a Science of the Technosphere's Sustainability. It is true that to ensure this sustainability we will have to think about using new technologies to repair and improve existing ones. However, this 


\begin{abstract}
"techno-fix" alone will never suffice. Public policies that normatively guide the evolution of the Technosphere, in particular its critical components, will also be necessary for its sustainability a la longue or in a horizon of multiple successive generations. The same is true of the need to create supranational institutions capable of effective and just global governance of the Technosphere. I believe this is also be one of the relevant implications of this work: an increase in awareness of this complex (and hopefully not wicked) problem of the sustainability of the Anthropocene Technosphere and of its perhaps more fearsome moral implication of the risk of civilizational collapse and extinction of our species.
\end{abstract}

Funding: This research received no external funding.

Institutional Review Board Statement: Not applicable.

Informed Consent Statement: Not applicable.

Conflicts of Interest: The author declares no conflict of interest.

\title{
Notes
}

1 Among its precursory notions (the list is not exhaustive) we have: V. Vernadsky's "Noosphere" (Vernadsky [1997] 1991), M. Heidegger's “Enframing (Gestell)” (Heidegger [1953] 1954), L. Mumford's “Megamachine” (Mumford 1967), J. Ellul's “Technological System (Système Téchnicien)” (Ellul 1977), G. Anders' “Universal Apparatus (Universalapparat)” (Anders 1980), and K. Kelly's “Technium” (Kelly 2010).

2 Four decades before the Canadian engineer, expert in control systems, John Milsum used the word in the title of a paper and argued that the Technosphere is distinct from other spheres of the Earth system, including the social sphere composed by all human beings (Milsum 1968). However, he didn't explore its philosophical significance.

3 Lescure (2017) followed an identical definition, but with some nuances: «The Technosphere, as defined by the EOS [Earth Organization for Sustainability], is basically our combined infrastructure and machine park, which build up the capability of human civilization to force multiply its efficiency in harvesting resources, while in the same time requiring maintenance. The Technosphere consists of transport systems, such as roads, railways (and in the future monorails and hyperloop systems), canals, ports and airports. It also consists of power plants and energy grids, as well as heating plants and sewage systems. It consists of the agricultural regions and facilities, the transport lanes of food to cities and the supermarkets or food depots where people acquire food. It consists of the mining facilities and other natural resource extraction operations, and the systems bringing these resources to refineries. It consists of the factories, which assemble refined resources into finished products, distributed to the markets and then sold to the consumers. It consists of research centres and universities, which serve to improve the efficiency of the infrastructure and to educate the future managers. And finally, it consists of the billions of people who staff this gargantuan daily operation of our civilisation as workers, engineers, scientists and managers.».

4 Extent (what portion of space it occupies) is not the same as weight (of the artefacts produced by humans, calculated in tons) or impact (measurement of the effects caused by these artefacts on the planet, e.g., on its atmosphere).

5 Haff (2013, p. 302) estimates that without the Technosphere, the human population would fall to values close to those it had in the Stone Age: from the present almost 8.000 million to about 10 million individuals.

6 Orig.: «Die Technosphäre ist—analog zur Biosphäre—das Aggregat aus technischen Artefakten, Ressourcen und nicht zuletzt auch Abfällen. Den soziotechnologisch gestalteten Lebensort des Menschen, eingerichtet mit dem Aggregat der technischen Artefakte, die einerseits unter gesellschaftlichen Bedingungen erzeugt, genutzt und verbraucht werden, sowie andererseits eben diese gesellschaftlichen Bedingungen durch ihre Herstellung, Installation und Anwendung hervorbringen, prägen und verändern, kann man analog zum Biotop als Technotop bezeichnen. Demgemäß ist das Technotop die vom Menschen bewohnte, technomorph ausgestaltete Region, seine soziotechnische Welt.».

7 This new planetary/technological condition has already started to generate an interesting body of critical literature, from which I want to highlight the following essays: (Chakrabarty 2015, 2018, 2019; Dufresne 2019; Hörl 2011; Scranton 2015).

\section{References}

Allenby, Braden. 2005. Reconstructing Earth: Technology and Environment in the Age of Humans. Washington: Island Press.

Anders, Günther. 1980. Die Antiquiertheit des Menschen Bd. II: Über Die Zerstörung des Lebens im Zeitalter der Dritten Industriellen Revolution. München: C. H. Beck.

Arendt, Hannah. 1998. The Human Condition, 2nd ed. Chicago and London: University of Chicago Press. First published 1958.

Arias-Maldonado, Manuel. 2015. Environment and Society: Socionatural Relations in the Anthropocene. Cham: Springer International.

Bakker, Karen, and Max Ritts. 2018. Smart Earth: A meta-review and implications for environmental governance. Global Environmental Change 52: 201-11. [CrossRef]

Baudrillard, Jean. 1983. Les Stratégies Fatales. Paris: B. Grasset. 
Ben-Eli, Michael. 2012. The cybernetics of sustainability: Definition and underlying principles. In Enough for all Forever: A Handbook for Learning about Sustainability. Edited by Joy Murray, Glenn Cawthorne, Christopher Dey and Chris Andrew. Champaign: Common Ground Publishing, pp. 255-68.

Bostrom, Nick, and Milan M. Ćirković, eds. 2008. Global Catastrophic Risks. Oxford: Oxford University Press.

Brundtland, Gro. 1987. Our Common Future: Report of the World Commission on Environment and Development. Dokument A/42/427. Geneva: UN.

Cera, Agostino. 2017. The technocene or technology as (Neo)environment. Techné: Research in Philosophy and Technology 21: $243-81$. [CrossRef]

Chakrabarty, Dipesh. 2015. The human condition in the Anthropocene. The Tanner Lectures in Human Values. pp. 18-19. Available online: https://tannerlectures.utah.edu/_resources/documents/a-to-z/c/Chakrabarty\%20manuscript.pdf (accessed on 22 September 2020).

Chakrabarty, Dipesh. 2018. Anthropocene time. History and Theory 57: 5-32. [CrossRef]

Chakrabarty, Dipesh. 2019. The Planet: An Emergent Humanist Category. Critical Inquiry 46: 1-31. [CrossRef]

Crutzen, Paul, and Eugene Stoermer. 2000. The "Anthropocene". Global Change Newsletter 41: 17-18.

Dalby, Simon. 2020. Anthropocene Geopolitics: Globalization, Security, Sustainability. Ottawa: University of Ottawa Press.

Döbel, Reinald. 2014. Sustainability-A historical and local perspective. In Communicative Sustainability. Negotiating the Future from the Periphery. Edited by Thomas Bearth, Rose Marie Beck and Reinald Döbel. Berlin, Münster and Zürich: Lit, pp. 35-66.

Donges, Jonathan F., Wolfgang Lucht, Finn Müller-Hansen, and Will Steffen. 2017. The Technosphere in Earth System Analysis: A Coevolutionary Perspective. The Anthropocene Review 4: 23-33. [CrossRef]

Dufresne, Todd. 2019. The Democracy of Suffering: Life on the Edge of Catastrophe, Philosophy in the Anthropocene. Montreal: McGill-Queen's University Press.

Ellul, Jacques. 1963. The Technological Order. Edited by Carl F. Stover. Detroit: Wayne State University Press, pp. 10-37.

Ellul, Jacques. 1977. Le Système Technicien. Paris: Calmann-Lévy.

Erlach, Klaus. 2000. Das Technotop. Die technologische Konstruktion der Wirklichkeit. Münster, Hamburg and London: LIT Verlag.

Erlach, Klaus. 2007. Wer oder was treibt Technik (an)?-Von der Eigendynamik zur. Gestaltungsfreiheit. In Bedingungen und Triebkräfte technologischer Innovationen. Edited by Klaus Kornwachs. Berlin: Acatech Diskutiert, pp. 117-40.

Fremaux, Anne. 2019. After the Anthropocene: Green Republicanism in a Post-Capitalist World. Cham: Palgrave MacMillan.

Gupta, Pamila, and Gabrielle Hecht. 2017. Toxicity, Waste, Detritus: An Introduction. Somatosphere. October 10. Available online: http:/ / somatosphere.net/2017/10/toxicity-waste-detritus-an-introduction.html (accessed on 29 April 2021).

Haff, Peter. 2012. Technology and human purpose: The problem of solids transport on the Earth's surface. Earth System Dynamics 3 : 149-56. [CrossRef]

Haff, Peter. 2013. Technology as a geological phenomenon: Implications for human well-being. In A Stratigraphical Basis for the Anthropocene. Edited by Colin Waters, Jan Zalasiewicz, Mark Williams, Michael Ellis and Andrea Snelling. London: Geological Society London, pp. 301-9.

Haff, Peter. 2014. Humans and technology in the Anthropocene: Six rules. The Anthropocene Review 1: 126-36. [CrossRef]

Hartley, John, Indrek Ibrus, and Maarja Ojamaa. 2020. On the Digital Semiosphere: Culture, Media and Science for the Anthropocene. New York: Bloomsbury Academic.

Heidegger, Martin. 1954. Die Frage nach der Technik. In Vorträge und Aufsätze. Edited by Martin Heidegger. Pfullingen: Günter Neske, pp. 5-36. First published 1953.

Herrmann-Pillath, Carsten. 2017. Foundational Issues of 'Technosphere Science'-The Case for a New Scientific Discipline. SSRN. [CrossRef]

Heßler, Martina. 2019. Technik und Autonomie. In Autonome Systeme und Arbeit. Perspektiven, Herausforderungen und Grenzen der Künstlichen Intelligenz in der Arbeitswelt. Edited by Hartmut Hirsch-Kreinsen and Anemari KaraČiĆ. Bielefeld: Transcript, pp. 247-74.

Hörl, Eric, ed. 2011. Die Technologische Bedingung. Beiträge zur Beschreibung der Technischen Welt. Berlin: Suhrkamp.

Hornborg, Alf. 2015. The political ecology of the Technocene: Uncovering ecologically unequal exchange in the world-system. In The Anthropocene and the Global Environmental Crisis: Rethinking Modernity in a New Epoch. Edited by Clive Hamilton, François Gemenne and Christophe Bonneuil. London: Routledge, pp. 57-69.

Hui, Yuk. 2017. On Cosmotechnics: For a Renewed Relation between Technology and Nature in the Anthropocene. Techné: Research in Philosophy and Technology 21: 1-23. [CrossRef]

Johnston, Paul, Mark Everard, David Santillo, and Karl-Henrik Robèrt. 2007. Reclaiming the Definition of Sustainability. Environmental Science and Pollution Research International 14: 60-66. [PubMed]

Karlsson, Rasmus. 2021. Learning in the Anthropocene. Social Sciences 10: 233. [CrossRef]

Kelly, Kevin. 2010. What Technology Wants. New York: Viking Press.

Kockelkoren, Petran. 2007. Mediated Vision: Introduction. In Mediated Vision. Edited by Petran Kockelkoren. Rotterdam: Veenman Publishers en ARTez Press, pp. 4-15.

Lescure, Enrique. 2017. The Technosphere and the Technate. Earth Organization for Sustainability. May 12. Available online: https:/ / eosprojects.com/the-technosphere-and-the-technate (accessed on 22 September 2020). 
Lucht, Wolfgang, and Carlo C. Jaeger. 2001. The Sustainability Geoscope: A Proposal for a Global Observation Instrument for the Anthropocene. Available online: https: / / citeseerx.ist.psu.edu/viewdoc/download?doi=10.1.1.574.2104\&rep=rep1\&type=pdf (accessed on 26 August 2020).

Meyer, Kate, and Peter Newman. 2020. Planetary Accounting: Quantifying How to Live Within Planetary Limits at Different Scales of Human Activity. Singapore: Springer.

Milsum, John. 1968. The technosphere, the biosphere, the sociosphere. Their systems modeling and optimization. IEEE Spectrum 5: 76-82.

Mumford, Lewis. 1967. The Myth of the Machine: Technics and Human Development. New York: Harcourt Brace Jovanovich.

Pearce, Annie, and Leslie Walrath. 2008. Definitions of Sustainability from the Literature. Available online: https://ja.scribd.com/ document/187314266/Definitions-of-Sustainability-From-the-Literature-Compiled-by-Annie-Pearce-Leslie-Walrath (accessed on 26 August 2020).

Reynolds, Jesse. 2021. Earth system interventions as technologies of the Anthropocene. Environmental Innovation and Societal Transitions 40: 132-46. [CrossRef]

Rockström, Johann, Will Steffen, Kevin Noone, Åsa Persson, F. Chapin III, Eric Lambin, Timothy Lenton, Marten Scheffer, Carl Folke, Hans Schellnhuber, and et al. 2009. A safe operating space for humanity. Nature 461: 472-75.

Scranton, Roy. 2015. Learning to Die in the Anthropocene. San Francisco: City Lights Books.

Smith, Laurence. 2011. The New North: Our World in 2050. London: Profile Books.

Soppelsa, Peter. 2017. Cities in the Technosphere. November 29. Available online: https://inhabitingtheanthropocene.com/2017/11/ 29/ cities-in-the-technosphere/comment-page-1 (accessed on 29 April 2020).

Steffen, Will, Katherine Richardson, Johan Rockström, Sarah Cornell, Ingo Fetzer, Elena Bennett, Reinette Biggs, Stephen Carpenter, Wim de Vries, Cynthia de Wit, and et al. 2015. Planetary Boundaries: Guiding human development on a changing planet. Science 347: 736. [CrossRef] [PubMed]

Steiner, Pierre. 2010. Philosophie, technologie et cognition: État des lieux et perspectives. Intellectica 53: 7-40. [CrossRef]

Suess, Eduard. 1875. Die Entstehung der Alpen. Wien: Braumüller.

Thomas, Julia. 2020. The Anthropocene Earth System and Three Human Stories. RCC Perspectives 3: 41-68.

Van Boeckel, Jan. 2015. Never mind where, as long as it's fast: Jacques Ellul and La Technique. Dark Mountain 8: $214-29$.

Vernadsky, Vladimir. 1991. Научная мысль как планетное явление. [Nauchnaya Mysl'kak Planetnoe Yavlenie/Scientific Thought as a Planetary Phenomenon]. Edited by L. A. Yashin. Translated by Boris Starostin. Moscow: Nauka, Moscow: Nongovernmental Ecological V.I. Vernadsky Foundation. First published 1997.

Wilde, Oscar. 1905. Intentions. The Decay of Lying. Pen Pencil and Poison. The Critic as Artist. The Truth of Masks. New York: Brentano's. First published 1889.

Zalasiewicz, Jan, Mark Williams, Colin Waters, Anthony Barnosky, John Palmesino, Ann-Sofi Rönnskog, Matt Edgeworth, Cath Neal, Alejandro Cearreta, Erle Ellis, and et al. 2017. Scale and diversity of the physical technosphere: A geological perspective. The Anthropocene Review 4: 9-22. [CrossRef] 